\title{
FLOWERING PATTERN, THE STRUCTURE OF NECTARY SURFACE AND NECTAR SECRETION IN TWO VARIETIES OF OCIMUM BASILICUM L.
}

\author{
Mirosława Chwil \\ Department of Botany, Agricultural University of Lublin, 20950 Lublin, Akademicka 15, Poland \\ e mail: miroslawa.chwil@ar.lublin.pl
}

Received: 5.02.2007

\section{S u m m a r y}

The studies conducted in the years 20032004 covered two varieties of Ocimum basilicum L.: var. purpurascens Benth. and var. lactucaefolium I. The flower lifetime, daily flowering pattern, morphology of pollen grains and the abundance of nectar secretion of flowers were compared. The surface of the nectaries of $O$. basilicum var. lactucaefolium was observed using scanning electron microscopy (SEM). The automorphic nectaries of basil formed the following parts: a flat part from the side of the upper lip and a convex part with three protrusions on the opposite side. On the top of two outer protrusions, stomatal areas were located, responsible for nectar secretion. The stomata occurred at the level of other epidermal cells. On the average, nectar contained $42 \%$ of sugars. The sugar yield of flowers of var. lactucaefolium was $36 \%$ higher than this feature in var. purpurascens. In terms of their size, the pollen grains were rated as medium sized. Their viability ranged $8896 \%$. The shape of the pollen grains was described as oblate and suboblate.

Key words: flowering, nectary, nektar secretions, stomata, cuticle, pollen grains, SEM, Ocimum basilicum, Lamiaceae

\section{INTRODUCTION}

The genus Ocimum numbers 150 plant species occurring in the natural environment in wild state, primarily in the tropical and subtropical zone of Africa and Asia (S zweykowscy, 2003). Basil belongs to the family Labiatae which includes a numerous group of melliferous plants recommended for cultivation in order to improve bee pollen benefits (Jabłoński, 1997b, 2000; Masierowska i Krzysiak, 2000; B ożek, 2003).

Plants from the genus Ocimum provide food attractants to insects in the form of pollen and nectar. Flowers of this species were visited in large numbers by insects, in particular honey bees (Raju, 1989; Malerbo-Souza i in. 2000). Nectar in the flowers of $O$. basilicum cv. Genovese contained a large concentration of sugars (Chwil, 2003). Studying the influence of different honey samples on resistant Staphylococcus-aureus strains, Garcia et al. (2001) showed that honeys from labiate plants inhibited most strongly the growth of staphylococcus.

Due to its favourable effect on human organism, showing anti-inflammatory, antibacterial and sedative activity, basil has found application in the pharmaceutical, food and cosmetics industries (Martyniak-Przybyszewska, 2000; Podbielkowski i Sudnik-Wójcikowska, 2003). Basil herb is used in phytotherapy, homeopathy and aromatherapy (Ko hlmünzer, 1993; Czy gan, 1997; Thoppil et al. 1998; Ndgounga i Ouamba, 1997).

The aim of the studies conducted was to compare ecological features of flowers, daily flowering pattern, nectar secretion and the morphology of pollen grains of two basil varieties. The morphology and structure of the secretory epidermis of the nectaries, as well as insect visitation of flowers of $O$. basilicum var. lactucafolium, were also determined.

\section{MATERIAL AND METHODS}

The studies conducted in the years 2003-2004 covered two varieties of Ocimum basilicum L.: var. purpurascens Benth. and var. lactucaefolium I. The taxa studied grew in the Botanical Garden of the Maria Curie-Skłodowska Univeristy in Lublin, Poland. The lifetime of flowers was estimated from the time of opening of lobels in the corolla until the wilting stage. The daily pattern of flower blooming was observed on five plants of each variety. Readings were made every hour between $7^{00}$ and $19^{00}$ on three sunny days. The visitation of flowers of var. lactucaefolium by pollinating insects was recorded at 2-hour intervals 
between $7^{00}$ and $19^{00}$. The abundance of nectar secretion of basil was examined using the pipette method. Nectar was collected three times in four samples at full bloom stage of the plants. One sample was the amount of nectar from the whole lifetime of $8-10$ flowers. The sugar yield was calculated from the weight of nectar and the percentage content of sugars in it, determined with an Abbe refractometer. The surface of the nectaries of O. basilicum var. lactucaefolium was observed using scanning electron microscopy (SEM). Morphometric measurements of the secretory tissue and flower elements were also made. The morphology of pollen grains was characterised, by determining the length of the equatorial (E) and polar (P) axis for 200 grains. To determine the pollen viability, the pollen was stained with acetocarmine. 400 grains were analysed in the successive view fields of a light microscope.

\section{RESULTS}

The plants of Ocimum basilicum var. lactucaefolium burst into bloom in the second decade of June. The variety purpurascens produced the first flowers several days later compared to the former variety. Buds of the studied varieties burst into bloom from early morning hours $\left(7^{00}\right)$ throughout the whole day until $17^{00}$. The largest number of blooming flowers on the plants of the both taxa was found at $11^{00}(32 \%-36 \%)$. The daily flowering pattern of the analysed varieties was similar. The intensity of formation of new flowers was the greatest between $9^{00}$ and $13^{00}$. The flower lifetime was 1.5 day (var. purpurascens) or 2 days (var. lactucaefolium) (Fig. 1). The observed varieties bloomed for a period of about three months.

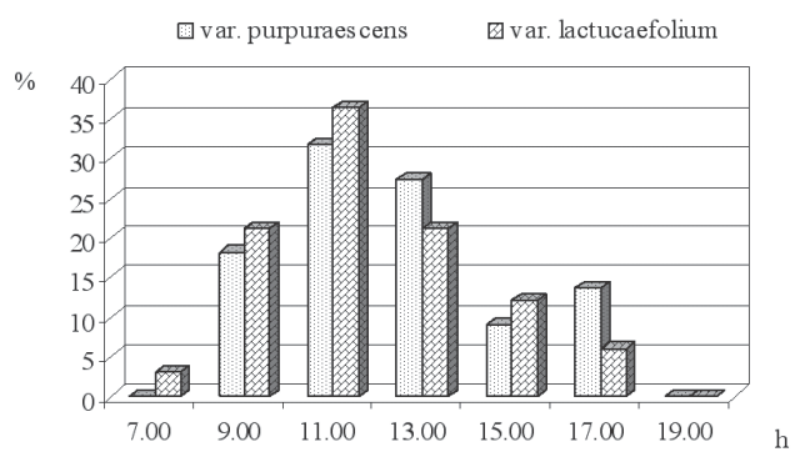

Fig. 1. Daily pattern of flower blooming in two varieties of Ocimum basilicum.

The flowers of the studied basil varieties differed in their size and the colour of the perianth. The flowers of $O$. basilicum var. lactucaefolium formed a shorter calyx (by $34 \%$ ) and a longer corolla (by $22 \%$ ) than these elements in the other variety (Fig. 2). Shining trichomes present on their surface and white (var. lactucaefolium) or purple-tinged colour (var. purpurascens) of the corolla (Figs. 5-8), as well as an intensive scent were signallers for insects. A short corolla tube $(5 \mathrm{~mm})$ provided easy access for insects to the nectar secreted (Tab. 2, Fig. 8). Numerous protective hairs growing on the surface of the epidermis covering the outgrowths of the filaments of two shorter stamens protected the nectar against evaporation (Fig. 9).

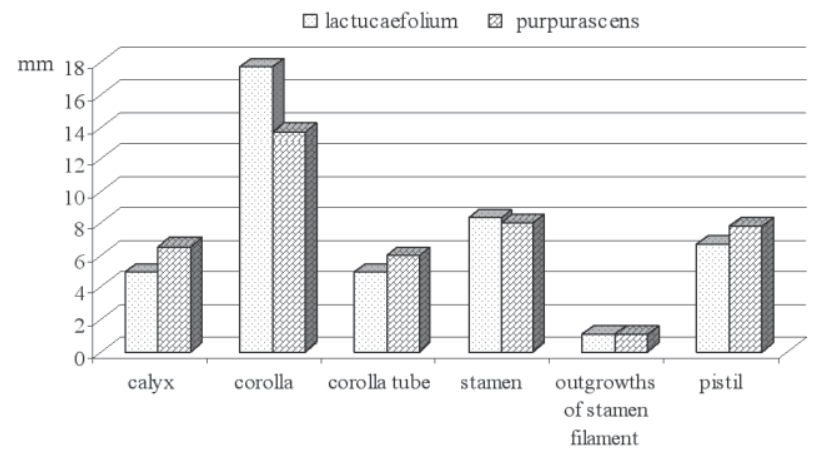

Fig. 2. Characteristics of flower elements of two varieties of Ocimum basilicum.

In the structure of the automorphic nectaries in the flowers of the studied basil, two parts were distinguished at the base of the ovary of the pistil: a flat part from the side of the upper lip and a convex part with three protrusions from the side of the lower lip. The convex fragments of the secretory tissue were situated between the parts of the four-parted ovary (Figs. 10-14). The glandular tissue from the side of the upper lip accounted for, on the average, $35 \%$ of the height of the protruding part $(100 \%=794 \mu \mathrm{m})$. The nectaries in the flowers of var. purpurascens had a larger size, lower protrusions and a thicker tier of cells in the flat part, compared to these parameters in the other variety (Fig. 3).

Nectar secretion in the basil flowers was observed from the bursting bud stage throughout their whole lifetime. The stomata forming clusters, that is, the stomatal areas on the two outer protrusions, were responsible for nectar secretion onto the nectary surface

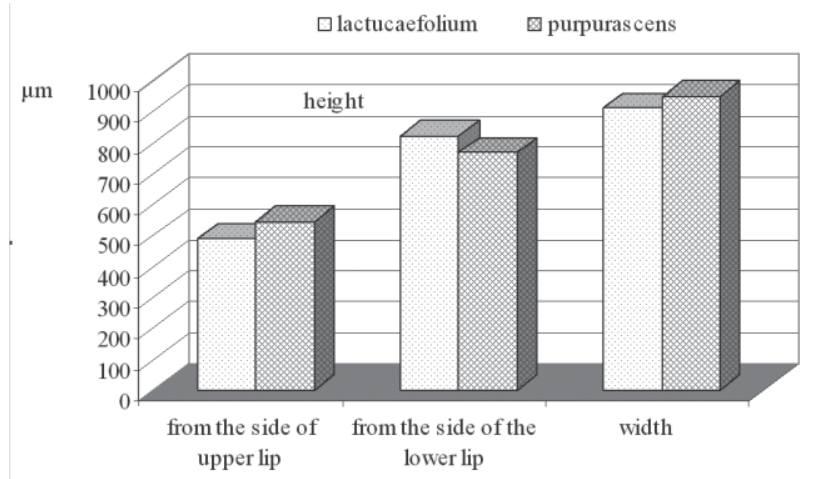

Fig. 3. Size of secretory tissue in flowers of two varieties of Ocimum basilicum. 
Table 1

Characteristics of secretory epidermis in flowersof Ocimum basilicum.

Trait studied

Number of stoma on the protrusion

$13 \quad 19$

\begin{tabular}{|c|c|c|c|}
\hline \multirow{2}{*}{ Size of stomatal cells } & length & \multirow{2}{*}{$(\mu \mathrm{m})$} & 21.34 \\
\hline & width & & 26.06 \\
\hline \multirow{2}{*}{ Cuticular ornamentation in the part of } & \multirow{2}{*}{ protrusion } & I, III & striated \\
\hline & & II & striated or smooth \\
\hline
\end{tabular}

Table 2

Abundance of nectar secretion of two varieties of Ocimum basilicum.

\begin{tabular}{ccccc}
\hline \multirow{2}{*}{ Variety } & Year & $\begin{array}{c}\text { Weight of nectar from } \\
\text { 10 flowers (mg) }\end{array}$ & $\begin{array}{c}\text { Sugar } \\
\text { concentrationin } \\
\text { nectar (\%) }\end{array}$ & $\begin{array}{c}\text { Weight of sugars from } \\
\text { 10 flowers (mg) }\end{array}$ \\
\hline \multirow{2}{*}{ lactucaefolium } & 2003 & 9.66 & 45.5 & 4.40 \\
\cline { 2 - 5 } & 2004 & 7.67 & 46.00 & 3.53 \\
\cline { 2 - 5 } purpurascens & $\bar{\chi}$ & 8.67 & 45.75 & 3.97 \\
\cline { 2 - 5 } & 2003 & 6.37 & 43.5 & 2.77 \\
\hline & 2004 & 5.54 & 42.0 & 2.55 \\
\hline
\end{tabular}

Table 3

Characteristics of pollen grains of two varieties of Ocimum basilicum.

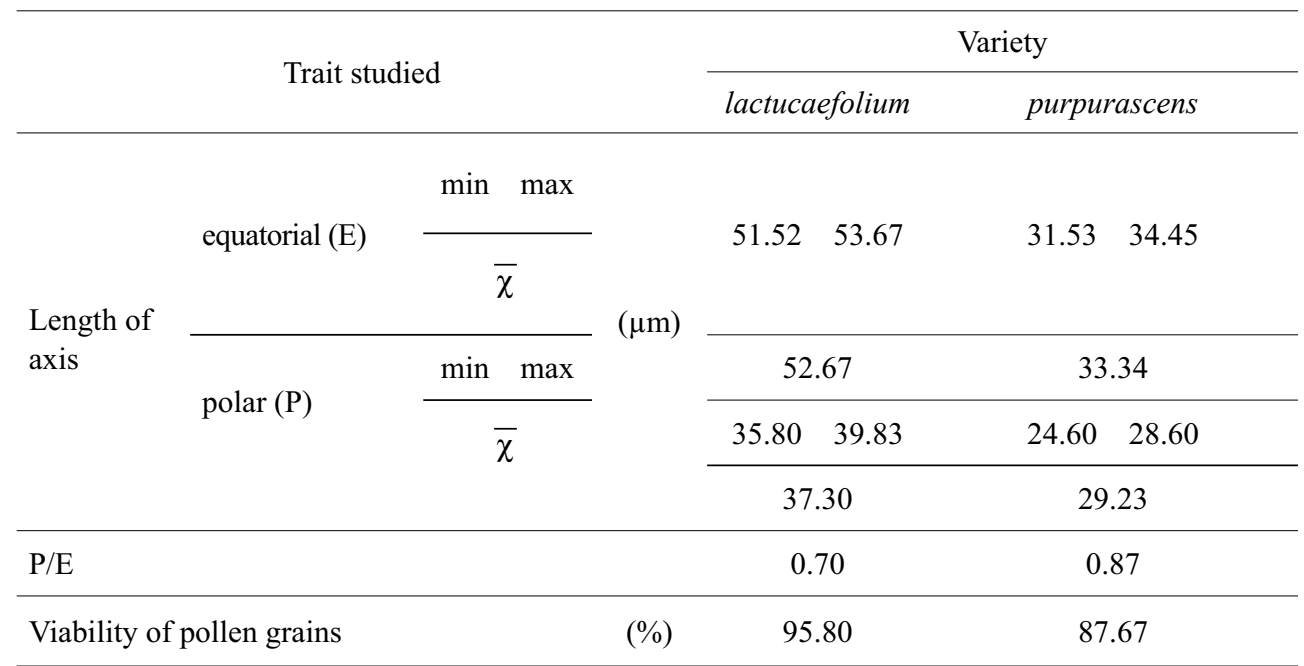

(Figs. 14-17). On each of them, the number of stomata ranged between 13 and 19. The width of the stomata was $26 \mu \mathrm{m}$, on the average, whereas the length 21 $\mu \mathrm{m}$ (Tab. 1). The stomata occurred on the tops of the protrusions and on their lateral edges on the outer and inner side (Figs. 16, 17, 19-21). No stomata were found on the flat part of the nectary and on the central protrusion (Figs. 15, 18). The modified stomata had various aperture of the pore, and the following stomata occurred: open, half-open and closed (Figs. 22-25). The stomatal cells occurred at the level of other cells of the epidermis or slightly beneath the epidermis, but only at 

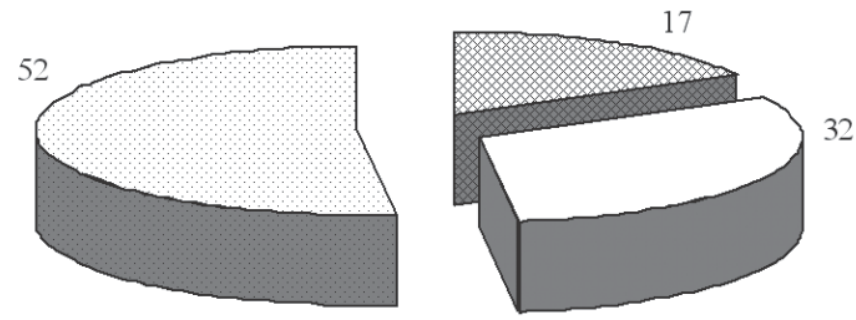

娄 another $\square$ bumblebees $\square$ honeybee

Fig. 4. Percentage shares of particular insect groups visiting flowers of Ocimum basilicum var. lactucaefolium.
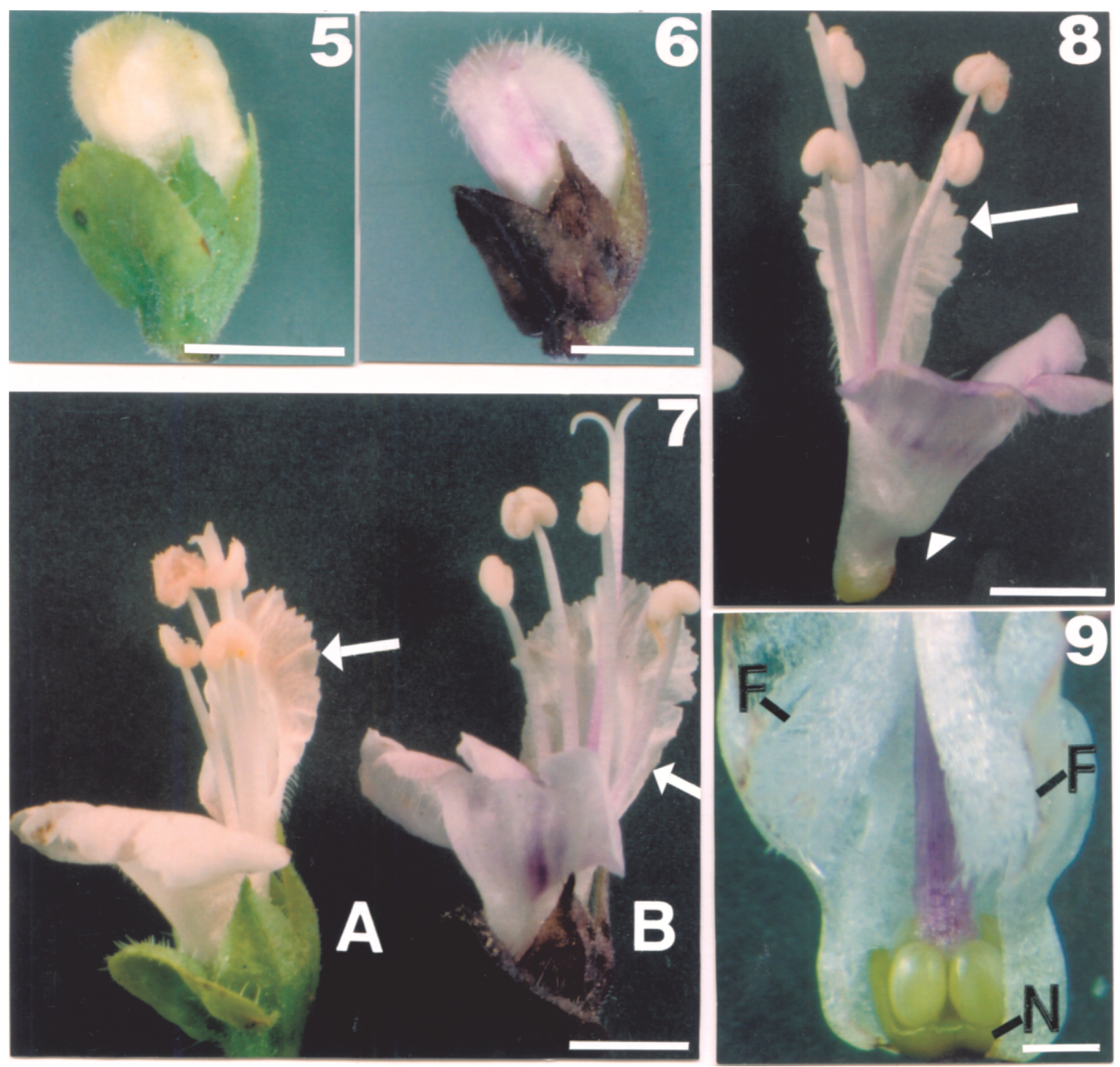

Fig. 5 9. Flowers of $O$. bassilicum L. at bud stage $(5,6)$ and at full bloom stage (7 9); lower lip (arrow), curvature of corolla visible (arrow head); 9 flat secretory tissue $(\mathrm{N})$ visible from the side of upper lip, outgrowths of stamen filaments (F) located in curvature of corolla (marked in Fig. 8 with arrow head). 5, 7a var. lactucaefolium; 6, 7b, 8,9 var.: purpurascens. Bar figs. 5, $62 \mathrm{~mm}$; figs. 7, $8 \quad 5 \mathrm{~mm}$; fig. $9500 \mu \mathrm{m}$. 

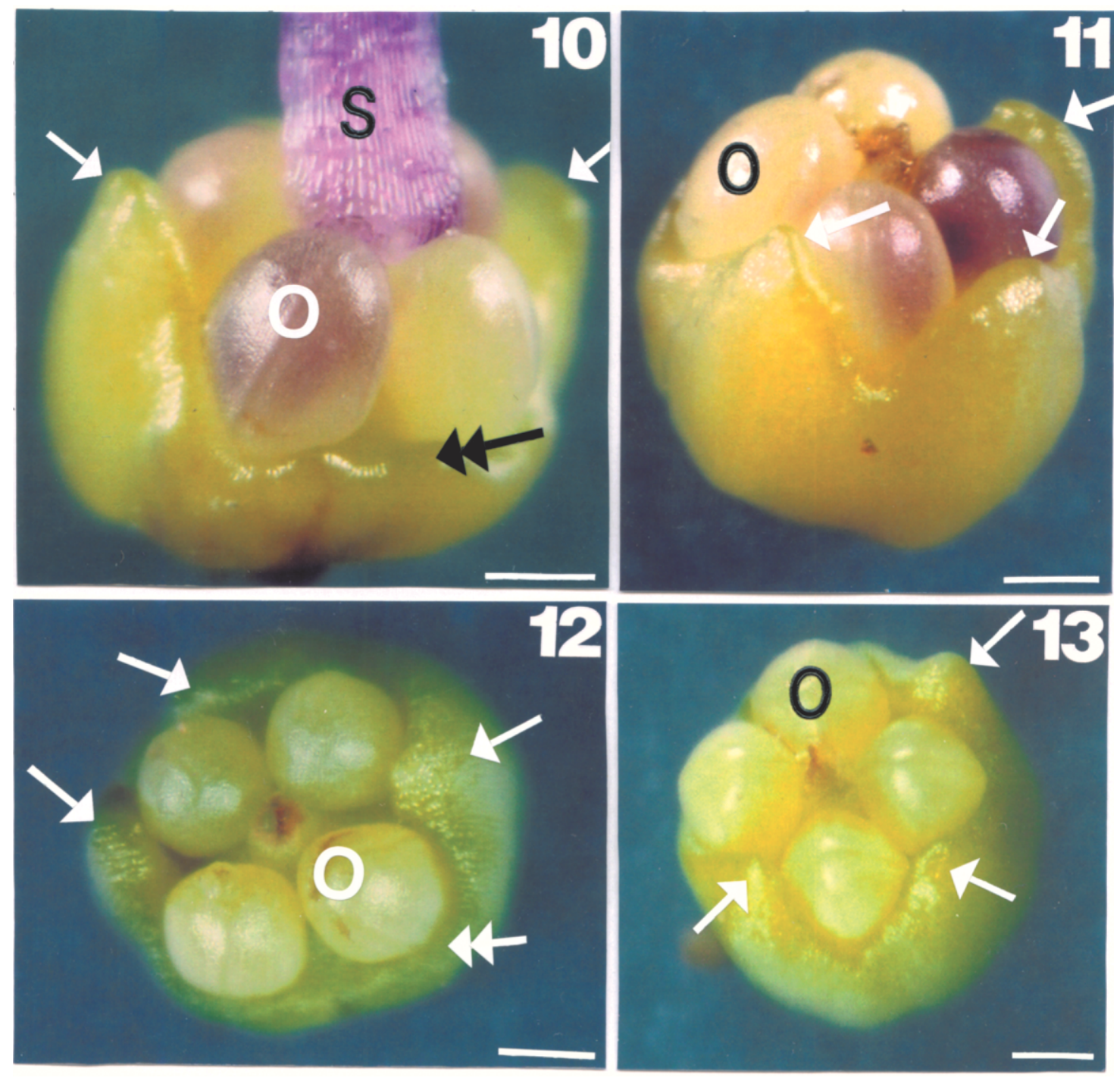

Figs. 10 13. Nectaries in flowers of $O$. bassilicum L. var.: purpurascens $(10,11)$ and lactucaefolium $(12,13)$; three protrusions of nectary from the side of upper lip visible (arrows) and flat part of secretory tissue located by upper lip (double arrow), style (S), ovary (O). Bar figs. $1013200 \mu \mathrm{m}$. 

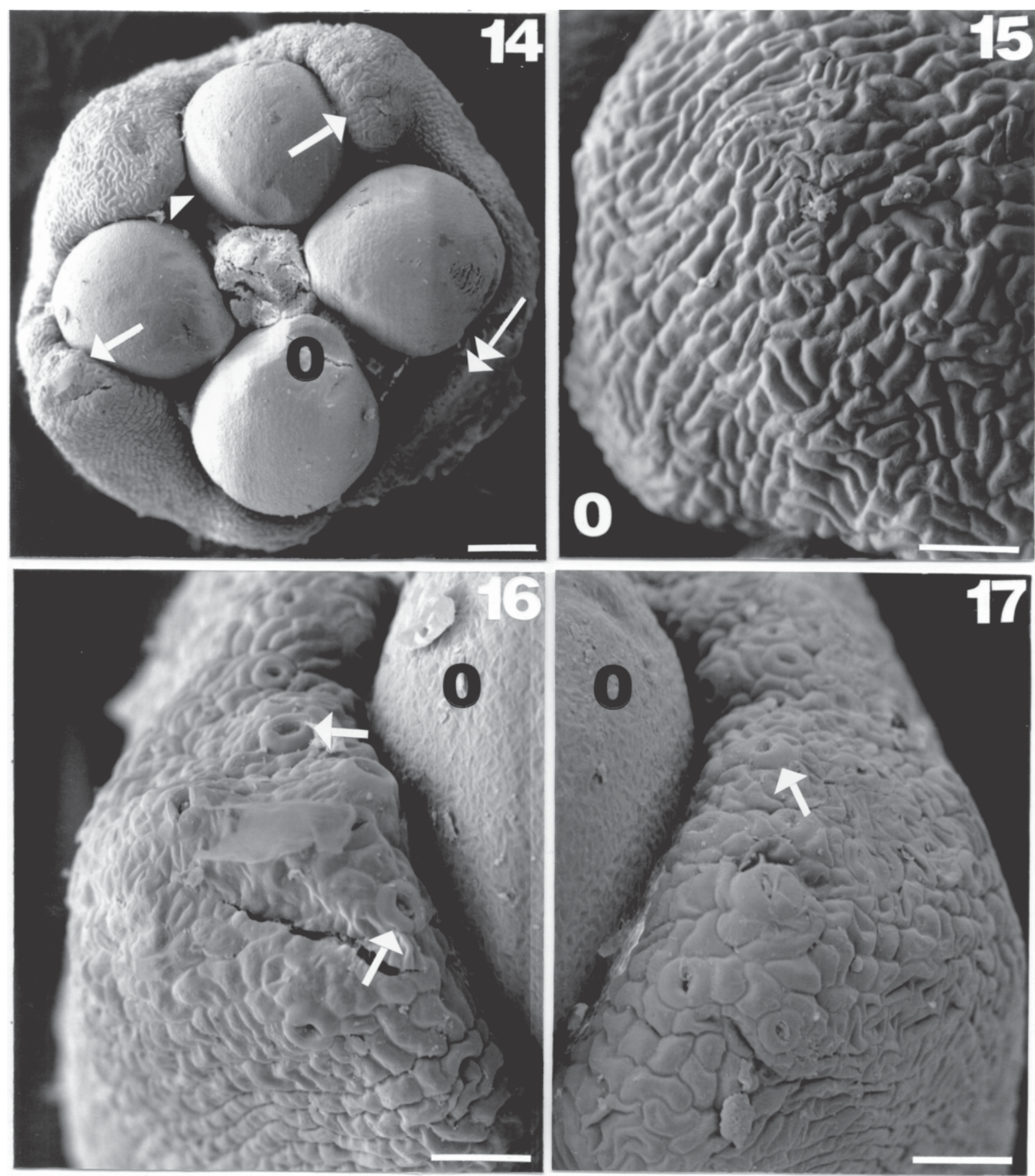

Fig. 14. Nectary visible from above in $O$. bassilicum L. var. lactucaefolium: flat part of nectary (double arrow), outer protrusions with stomatal areas (arrows), central protrusion of secretory tissue (arrow head), ovary (O). Bar figs. $1013 \quad 100 \mu \mathrm{m}$. Bar fig. 14 $100 \mu \mathrm{m}$.

Figs. 15 17. Fragments of nectary of $O$. bassilicum L. var. lactucaefolium; 15 cells of epidermis are visible covering central protrusion of secretory tissue with smooth cuticle or slight striation 16, 17 outer protrusions developing stomata (arrows), ovary (O) Bar figs. $1517 \quad 100 \mu \mathrm{m}$. 

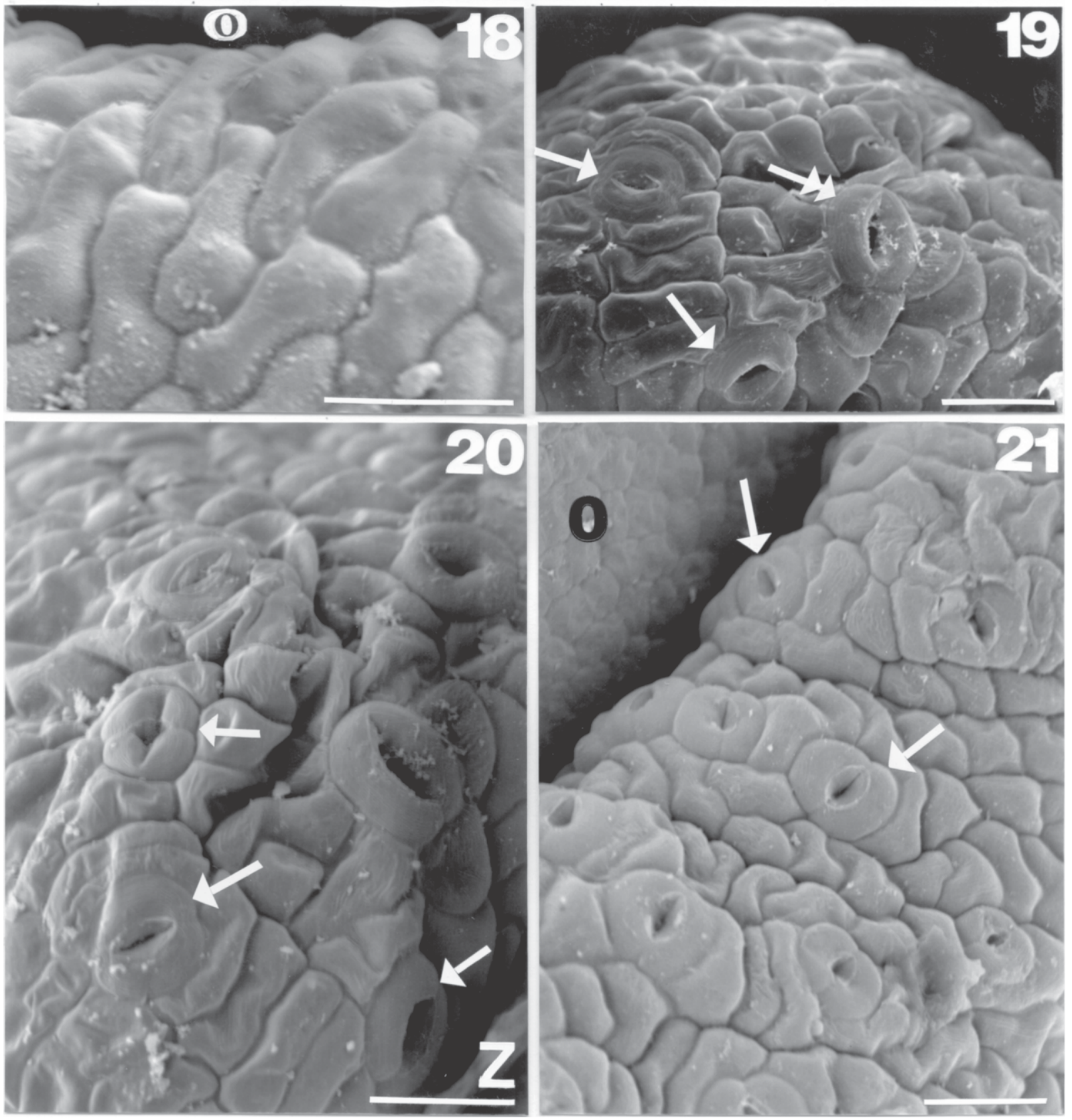

Figs. 18 21. Fragments of secretory tissue of $O$. bassilicum L. var. lactucaefolium; ovary (O). 18 surface of epidermis covering flat part of nectary; cells with smooth cuticle visible 19 tip of protrusion with stomata located at the level other epidermal cells (arrow) or slightly beneath them (double arrow). 20,21 cells of secretory epidermis covering inner (20) and outer side of protrusion (21), stomata (arrow). Bar figs. $18 \quad 21 \quad 30 \mu \mathrm{m}$. 

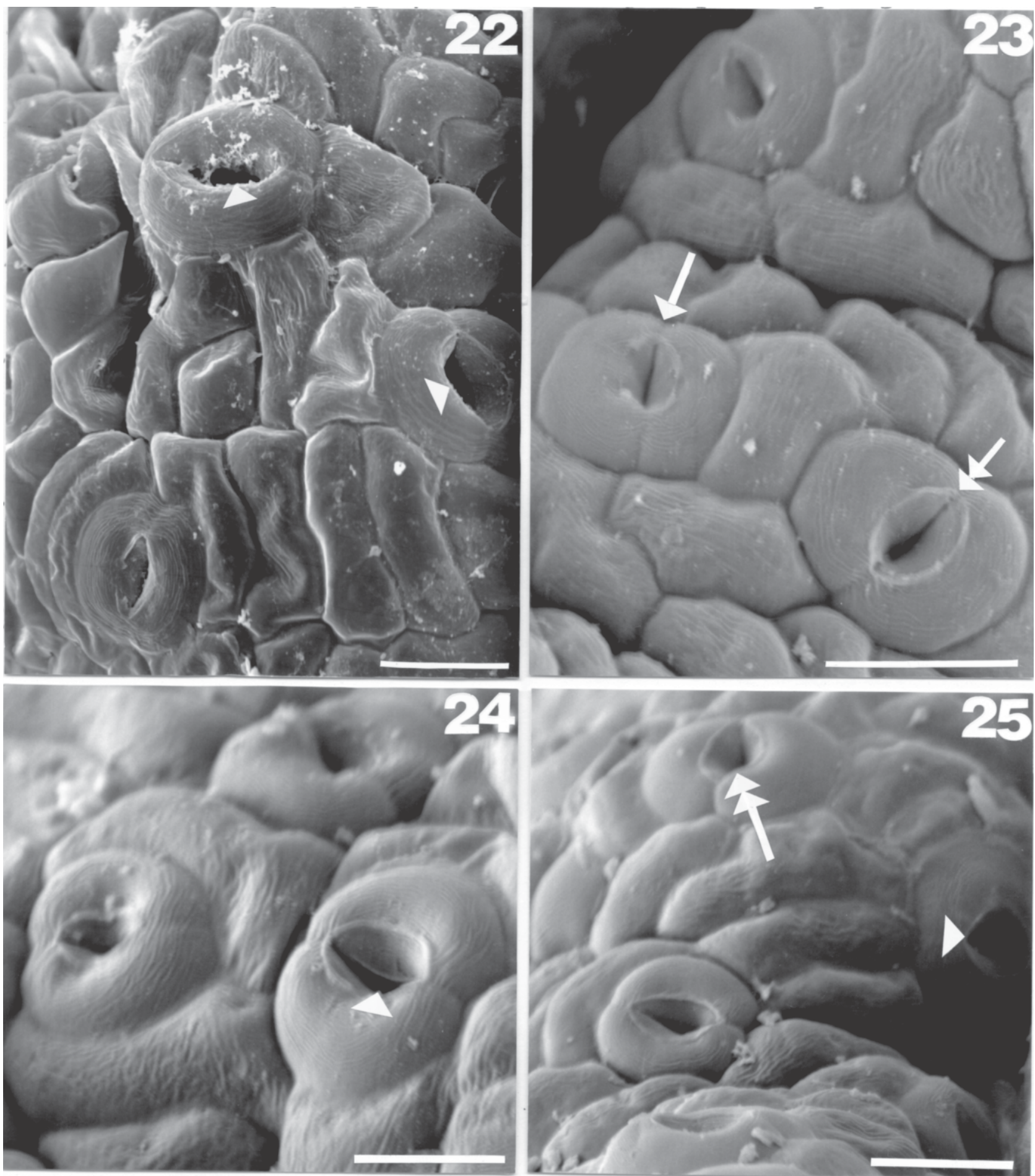

Figs. 22 25. Frag ments of glandular epidermis of $O$. bassilicum L. var. lactucaefolium; stomata visible: closed (arrow), half open (double arrow) and open (arrow head), as well as cuticular, semi spherical striae arranged around stoma or along longer axis of epidermal cells. Outgrowth of stamen, height from the side of lower lip and upper lip. Bar figs. $222520 \mu \mathrm{m}$. 
the top of the secretory protrusions (Figs. 19-21). The cuticle on the surface of the stomatal cells formed spherical, thin and densely arranged striae surrounding the stoma. This layer on the surface of other cells developed fine striation arranged along the longer axis of the cells or it was smooth (Tab. 1, Figs. 18-21).

The studied basil varieties secreted nectar abundantly. Ten flowers of var. lactucaefolium secreted about $9 \mathrm{mg}$ of nectar. The weight of nectar in the flowers of var. purpurascens was found lower by $31 \%$ compared to the former variety. The concentration of sugars in nectar ranged $43-46 \%$. When comparing the sugar content in this solution, it was found that the sugar yield of the flowers of var. lactucaefolium was $36 \%$ higher than the weight of sugar in the nectar of the other variety (Tab. 1).

Insects also collected pollen from the basil flowers. The high pollen viability ranging $88-96 \%$ evidences its good nutritional value for insects. The six-colpate white pollen grains of basil developed a reticulate sculpture of the exine. A comparison of the length of the equatorial and polar axis of the grains shows that the flowers of var. purpurascens produced smaller pollen grains compared to the pollen of the other variety. In terms of the size, the pollen grains of basil were classified as medium-sized. Based on the shape index $(\mathrm{P} / \mathrm{E})$, these grains were classified as oblate in the flowers of var. lactucaefolium and suboblate in the anthers of var. purpurascens (Tab. 2).

The main insects visiting the basil flowers were bees and bumblebees. Honey bees accounted, on the average, for $52 \%$ of insects recorded. The share of bumblebees in flower visitation was $31 \%$. Visitations of other insects accounted for $17 \%$ of all pollinators recorded (Fig. 4).

\section{DISCUSSION}

The lifetime of basil flowers depends on the variety and climatic conditions. In the varieties studied, this period was $1.5-2$ days. A shorter flowering stage of a single flower was found under other climatic conditions in $O$. basilicum (30 hours.) (Malerbo-Sauza et al. 2000), whereas a longer one in cv. Genovese (2-3 days) (Chwil, 2003). The observed varieties and other Lamiaceae species described in literature were divided into two groups in terms of blooming time. The first one includes plants producing new flowers throughout the whole day (the studied species of basil, $O$. basilicum cv. Genovense, Lavendula latifolia) (Chwil, 2003; Jabłoński, 1990). Whereas the other group comprises plants with flowers blooming at afternoon hours (self heal and savoury) (Jabłoński, 1997a, b).

The nectaries in the flowers of the studied basil were rated as automorphic. This type is characteristic for representatives of the family Lamiaceae (Wróblew ska,
1999; Weryszko-Chmielewska and Chwil, 2002; Chwil, 2003). A similar structure of nectaries was found in: Nepeta foliosa, Hyssopus officinalis, Origanum vulgare and Mentha spicata (We ry s z k o-C h mi e le w s ka, 2000; Weryszko-Chmielewska and Chwil, 2002). The nectaries of the observed basil species and Lamiaceae species described in literature are arranged in terms of the height as follows: $O$. basilicum var. lactucaefolium $<\mathrm{O}$. basilicum var: purpurascens $<O$. basilicum cv. Genovese < Nepeta grandiflora (Weryszko-Chmielewska and Chwil, 2002; Chwil, 2003). Weryszko-Chmielewska (2000), taking into account the shape and number of protrusions in the nectaries, distinguished their three groups in the family Lamiaceae: irregular with three protrusions, symmetrical with one protrusion and regular with a symmetrically divided tissue.

The nectar in the flowers of the studied basil was secreted by the stomata located on two outer convexities of the nectary. Their number on a single protrusion was 13-19. In several earlier described Labiate taxa, this parameter ranged between 4 and 18 (Weryszko-Chmielewska, 2000). Most of the modified stomata in the secretory epidermis of the analysed varieties of basil occurred at the level of other cells. A similar position of the stomata was found by Dafni et al. (1988) in the nectaries of Pholomis viscosa, Rosmarinus officinalis and Salvia fruticosa, whereas in Coridothymus capitatus and Melissa officinalis these cells were elevated over the epidermis surface or depressed as in Salvia hiersohymitana.

Nectar secretion in the flowers of the analysed basil continued throughout their whole lifetime. An identical secretion pattern was noted in Ocimum kilimandscharicum and $O$. gratissimum, with the maximum amount of nectar at 10.00 in the former taxon and at 12.00 in the latter (Sajjanar i in. 2005a).

The concentration of sugars in the studied basil was $45 \%$, on the average, and their weight from ten flowers ranged 2.6-3.5 mg. This value was higher than the sugar yield of: O. gratissimum, Dracocephalum moldavica, Nepeta melissiflora, Salvia glutinosa and $S$. Przewalski, but it was lower than the yield of $O$. basilicum cv. Genovese, O. kilimandscharicum (Masierowska and Krzysiak, 2000; Chwil, 2003; Sajjanar et al., 2005a; Weryszko-Chmielewska et al., 2005). The hairs present in the epidermisco vering the outgrowths of the stamens protected the nectar against evaporation in the flowers of the observed varieties of basil. According to B a n a z a k (1987), these trichomes also made it impossible for insects unable to cross pollinate flowers to use the nectar.

From the flowers of the studied basil and basil described in literature, insects collected pollen and formed white pellets (Raju, 1989). In terms of the size, the 
pollen grains of the tested varieties were classified as medium-sized. A similar size of pollen was found in the flowers of: $O$. americanum, $O$. circinatum, $O$. cufodontii, $O$. fisherii, $O$. micranthum. Large grains were also observed in the anthers of: $O$. americanum, O. basilicum, $O$. basilicum cv.Genovese, $O$. circinatum, $O$. fischeri, whereassmallgrainswerenotedintheflowersofO.campechianum, $O$. circinatum (Armbruster and Jacobs, 1934; Harley et al., 1992; Corrêa and Esteves, 1996; Chwil, 2003; Beug, 2004). The shape of the pollen grains of the analysed basil and basil described by other authors was classified as oblate (var. lactucaefolium), suboblate (var. purpurascens, cv. Genovese), oblatoand prolatosferoidal (O. micrantum) (Harley et al. 1992; Corrêa, 1996; Weryszko-Chmielewska and $\mathrm{Chw}$ il, 2002; Chwil, 2003). In the classification of pollen grains of different species from the genus Ocimum, three sections were distinguished: Ocimum, Hierocymum and Gymnocymum. The pollen of Ocimum basilicum was classified in the Ocimum section and subsection differing in the shape of grains and exine sculpture (Harley et al., 1992).

The main insects visiting basil flowers were honey bees (52\%). In the studies of Malerbo-Souza et al. (2000), visits of Apis mellifera in Ocimum flowers accounted for $98 \%$, whereas Diptera and Lepidoptera were encountered sporadically. The duration of a visit of a single flower of $O$. gratissimum depended on the bee species and the type of food collected. For pollen it was 5-14 seconds, whereas for nectar this time was longer (6-34 s). The foraging frequency of Apis mellifera in the flowers of several Ocimum species increased between 6.00 and 15.00 , later it decreased. Under other study conditions, its foraging lasted until 18.00 (Sajjanar et al. 2005b, c; Malerbo-S ouza et al., 2000).

Due to its high sugar yield and a long flowering period, basil may be considered as a good source of nectar for honey bees. On the other hand, the small number of sterile grains evidences their good nutritional value for insects, a high efficiency of cross pollination and the possibility to create new forms in breeding works.

\section{REFERENCES}

Armbruster L., Jacobs J., 1934. Pollenformen und Hoigherkunft. Verlag des Archiv für Bienenkunde, Berlin.

Banaszak J., 1987. Pszczoły i zapylanie roślin. PWRiL, Poznań.

Beug H. J., 2004. Leitfaden der Pollenbestimmung für Mitteleuropa und angrenzende Gebiete. Verlag Dr. Friedrich Pfeil, München.

Bożek M., 2003. Wydajność pyłkowa i oblot przez owady zapylające trzech gatunków roślin z rodzaju kocimiętka (Nepeta L.). J. Apic. Sci. 47(2): 1924.
Chwil M., 2003. Biologia kwitnienia i nektarowanie bazylii (Ocimum basilicum cv. Genovese). Ann. Univ. Mariae Curie Skłodowska, sect. EEE, Hortic. 13: 118121.

Corrêa A. M. S., Esteves L. M., 1996. Flora polínica da reserve do paraque estadual das fontes do ipiranga (São Paulo, Brasil). Hoehna 1996, 23(1): 141145.

Czygan F., 1997. Basilikum Ocimum basilicum L. Zeitschrift für Phytotherapie, 18. 5866.

Dafni H., Lensky Y., Fahn A., 1988. Flower and nectar characteristics of nine species of Labiatae and their influence on honey bee visits. J. Apic. Res. 27(2): 103104.

Garcia M., Perez Arquillue C., Juan T., Juan M. I., Herdera A., 2001. Note. Pollen analysis and antibacterial activity of Spanish honeys. Food Sci. Tech. Inter. 7(2): 155158.

Harley M. M., Paton A., Harley R. M., Cade P. G., 1992. Pollen morphological studies in tribe Ocimeae (Nepetbideae: Labiatae): I. Ocimum L. Grana, 31: 161176.

Jabłoński B., 1997a. Cząber ogrodowy roślina przyprawowa, lecznicza i miododajna. Pszczelarstwo, 48(1): 8.

Jabłoński B., 1997b. Wartość pszczelarska głowienki pospolitej. Pszczelarstwo 48(8): 11.

Jabłoński B., 2000. Kłosowce wspaniałe rośliny miododajne. Pszczel. Pol. 2, 56: 2021.

Jabłoński B., Szklanowska K., 1979. Propozycje zmiany metody badań nektarowania roślin. Pszczel. Zesz. Nauk. 23: 105113 .

Kohlmünzer S., 1993. Farmakognozja. PZWL, Warszawa.

Malerbo Souza D. T., Mota M. O. S., Nogueira Couto R. H., Souza J. C., 2000. Insects associated to the inflorescences of basil (Ocimum basilicum L.). Rev. Brasil. Plant. Med., 2(2): 2730.

Martyniak Przybyszewska B., 2000. Bazylia pospolita (Ocimum basilicum L.) cenna roślina przyprawowa. Biul. Nauk. 8:273 276.

Masierowska M., Krzysiak K., 2000. The preliminary studies on flowering biology and melliferous value of three perennial species from Lamiaceae family. Pszczel. Zesz. Nauk. 44(2): 245253.

Ndounga M., Ouamba J. M., 1997. Antibacterial and antifungal activities of essential oils of Ocimum gratissimum and $O$. basilicum from Congo. Fitoterapia, 68(2): 190191.

Podbielkowski Z., Sudnik Wójcikowska B., 2003. Słownik roślin użytkowych. PWRiL, Warszawa.

Raju A. J. S. 1989. Reproductive ecology of Ocimum americanum L. and $O$. basilicum L. (Lamiaceae) in India. Plant Spec. Biol. 4: 107116.

Sajjanar S. M., Kuberappa G. C., Eswarappa G. 2005a. Nectar secretion and sugar concentration in Ocimum species an important honey bee forage plant. Mys. J. Agric. Sci. 39(2): 284285.

Sajjanar S. M., Prabhuswamy H. P., Kuberappa G. C., 2005b. Foraging behaviour of honeybees on spice basil 
(Ocimum gratissimum L.) in relation to the quantity and sugar concentration in its nectar. Mys. J. Agric. Sci. 39(2): 145150 .

Sajjanar S. M., Prabhuswamy H. P., Kuberappa G. C., $2005 \mathrm{c}$. Insect pollinators and their relative abundance on spice basil (Ocimum gratissimum L.). Mys. J. Agric. Sci. 39(1): 1013.

Szafer W., Wojtusiakowa H., 1969. Kwiaty i zwierzęta Warszawa.

Szweykowscy A. J., 2003. Słownik Botaniczny. Wiedza Powszechna, Warszawa.

Thoppil E., Tajo A., Minija J., 1998. Antibacterial and antifungal activity of four varieties of Ocimum basilicum. Fitoterapia, 69(2): 191192.
Weryszko Chmielewska E., 2000. Ecological features of flowers including nectary structure of chosen species from Lamiaceae family. Pszczel. Zesz. Nauk. 2: 223232.

Weryszko Chmielewska E. i Chwil M., 2002. Blooming and nectar secretion of Nepeta grandiflora Bieb. under the condition of load excess. J. Apic. Sci. 46(1): 5965.

Weryszko Chmielewska E., Dmitruk M., Kwiatkowski S., Wolski T., 2005. Nektarowanie i wydajność miodowa dwu form pszczelnika mołdawskiego (Dracocephalum moldavica L.). XLII Naukowa Konferencja Pszczelarska. Puławy, 89 marca: 121122.

Wróblewska A., 1999. Monarda hybrida Hort. jako źródło pożytku dla pszczół. Bibl. Fragm. Agron. 6: 19174. 
